\title{
AKTIVITAS ANTIOKSIDAN KURMA TOMAT (Solanum lycopersicum) DENGAN VARIASI JENIS JAHE DAN LAMA PENGERINGAN
}

\author{
Antioxidant Activity of Tomato Dates (Solanum lycopersicum) \\ with Various Types of Ginger and Drying Time
}

\author{
Wahyu Risnantoko, Nanik Suhartatik, Akhmad Mustofa \\ Fakultas Teknologi dan Industri pangan Universitas Slamet Riyadi Surakarta, \\ Jl. Sumpah Pemuda 18 Joglo Kadipiro Surakarta 57136 \\ Email: naradhitadewi96@gmail.com
}

\begin{abstract}
ABSTRAK
Tomat adalah salah satu sumber antioksidan alami. Dibalik manfaat buah tomat yang baik untuk kesehatan. Buah tomat sangat mudah mengalami kerusakan. Penelitian ini memanfaatkan buah tomat untuk dijadikan manisan tomat (kurma tomat). Tomat pada umumnya memiliki kandungan antioksidan yang tinggi tetapi perlakuan pemanasan akan mengurangi jumlah antioksidan, sehingga penambahan bahan lain yang memiliki kandungan antioksidan sangat diperlukan. Jahe merupakan bahan yang mengandung antioksidan yang cukup tinggi dan akan ditambahkan pada kurma tomat. Tujuan dari penelitian ini adalah untuk mengetahui karakteristik dan aktivitas antioksidan tertinggi pada kurma tomat dengan penambahan jenis jahe dan lama pengeringan serta disukai konsumen.

Perlakuan yang diberikan meliputi penambahan jenis jahe, yaitu jahe gajah, emprit, dan jahe merah. Perlakuan yang kedua adalah lama pengeringan, yaitu selama 18, 20, dan 22 jam. Hasil penelitian menunjukkan bahwa penambahan jenis jahe dan lama pengeringan berpengaruh nyata terhadap karateristik kimia dan organoleptik kurma tomat. Aktivitas antioksidan tertinggi adalah 27,12\%, untuk kadar air sebesar $20,76 \%$, kadar $\beta$ karoten sebesar 11,51\%, kadar gula total sebesar 39,23\%, $\mathrm{pH} 5,8$; warna $(2,7)$; rasa $(1,7)$ aroma $(2,2)$; kealotan $(1,6)$; kesukaan keseluruhan $(2,8)$. Nilai kesukaan paling tinggi dihasilkan pada perlakuan penambahan jenis jahe gajah dengan lama pengeringan selama 18 jam.
\end{abstract}

Kata kunci: kurma tomat, jahe, antioksidan.

\begin{abstract}
Tomato was one of natural antioxidants source. Behind the benefits, tomato was good for health. Tomatoes are easily damaged. Tomatoes generally has high antioxidants content but the heating treatment will reduce compound of antioxidants. The addition of ingredients that have antioxidant content is also necessary. Ginger is one of ingredients contain antioxidant that will be added to the tomato dates. The purposes of this study were to find out the characteristics and antioxidant activities of tomato dates with the addition of ginger variety and drying time and consumer preference.

The treatments include the addition of ginger variety, such as gajah ginger, emprit, and red ginger. The second treatment was time needed for drying, that were 18,20 , and 22 hours. The results showed that the addition of ginger variety and drying time had significant effect on chemical characteristics and organoleptic of tomato dates. The tomato dates has antioxidant activity of $27.12 \%, 20.76 \%$ of water content, $11.51 \%$ of $\beta$ carotene, $39.23 \%$ of total sugar level and $\mathrm{pH}$ value 5.8 , colour $(2,7)$; tasty $(1,7)$; flavor $(2,2)$; odds $(1,6)$; and overall fondness $(2,8)$. As the result, the highest favorite value resulted in the addition of gajah ginger and 18 hour of drying times..
\end{abstract}

Keywords: tomato dates, ginger, antioxidant. 


\section{PENDAHULUAN}

Tomat merupakan salah satu buah yang memiliki banyak manfaat. Namun sayangnya, tomat hanya dimanfaatkan sebagai bumbu masakan dan lalapan saja. Berdasarkan hasil penelitian sebelumnya (Alda dkk., 2009), kandungan likopen (sumber antioksidan) olahan buah tomat ternyata cenderung lebih besar daripada kandungan likopen pada tomat yang masih segar. Buah tomat yang masih segar memiliki kandungan likopen sekitar $12 \mathrm{mg} / \mathrm{1oog}$. Produk olahan tomat memiliki kandungan likopen yang cenderung lebih besar yaitu sekitar $16 \mathrm{mg} / 100 g$.

Aktivitas antioksidan dalam buah tomat ini bersumber dari beberapa senyawa yang terkandung dalam buah tomat, di antaranya likopen dan $ß$-karoten yang termasuk ke dalam golongan karotenoid. Antioksidan yang paling tinggi dalam buah tomat adalah likopen (Budiman, 2008). Dibalik manfaat buah tomat yang banyak tersebut buah tomat sangat mudah untuk mengalami kebusukan jika tidak dilakukan perlakuan pasca panen seperti pengeringan.

Nilai konsumsi dari buah tomat dapat ditingkatkan dengan mengolah buah tomat menjadi manisan. Manisan merupakan salah satu jenis makanan ringan yang biasanya menggunakan gula pasir sebagai bahan pemanis untuk memperoleh tingkat kekerasan yang cukup stabil. Manisan tomat ini jika sudah jadi akan memiliki bentuk seperti kurma dan rasanyapun menyerupai kurma, sehingga manisan tomat ini bisa disebut dengan kurma tomat.

Tomat pada umumnya memiliki kandungan antioksidan yang tinggi tetapi perlakuan pemanasan akan mengurangi jumlah antioksidan. Penambahan bahan yang memiliki kandungan antioksidan juga sangat diperlukan. Jahe merupakan bahan pangan yang mengandung antioksidan sehingga akan ditambahkan pada kurma tomat. Selain sebagai penambah antioksidan pada kurma tomat jahe juga memperkaya rasa pada kurma tomat.

Jahe mengandung senyawa yang bernama oleoresin atau yang lebih dikenal dengan nama gingerol, senyawa tersebut bersifat antioksidan sehingga sangat berguna bagi kesehatan, di antaranya dapat mengobati penyakit urusurus, masuk angin, cacingan, encok, bronkitis, asma, jantung, memperbaiki pencernaan, dan memperbaiki imun (Darwis dkk, 1991). Jahe yang ditambahkan dalam kurma tomat ini adalah jenis jahe gajah, jahe emprit, dan jahe merah.

Penambahan jenis jahe dalam pembuatan kurma tomat diharapkan dapat meningkatkan nilai gizi manisan tomat terutama antioksidan. Antioksidan memiliki sifat yang sensitif terhadap panas dan cahaya, maka dari itu dalam proses pembuatan pangan sumber antioksidan harus dihindarkan dari faktor-faktor yang dapat menurunkan aktivitas antioksidan. Tetapi untuk pengembangan produk yang memiliki aktivitas antioksidan ketersediaan bahan harus secara terus-menerus, sedangkan bahan yang masih segar mudah terjadi kerusakan dibanding dengan bahan yang sudah mengalami proses pengeringan. Pengeringan dapat mengurangi kadar air, sehingga dapat menambah umur simpan kurma tomat.

Oleh karena itu, perlu dilakukan penelitian untuk mengetahui jenis jahe dan lama pengeringan yang tepat dalam pembuatan kurma tomat terhadap aktivitas antioksidan. Pengeringan berfungsi untuk memperbaiki tekstur dan jahe untuk meningkatkan antioksidannya.

\section{METODE PENEITIAN}

Alat

Alat yang digunakan adalah destilator, spektrofotometer (Thermo Scientific), water bath (Memmert), vortex VM3oo (merk K), oven (Nabertherm), muffle (memmert), timbangan analitik (adventurer), dan kurs porselen.

\section{Bahan}

Tomat dan jahe yang didapatkan dari pasar tradisional yang ada di sekitar Solo. Bahan analisis yang digunakan adalah aquadest, larutan BSA, xylene, alkohol 96\%, DPPH Aldrich, $\mathrm{HCl} 25 \%, \mathrm{NaOH} 50 \%$.

\section{Ranacangan Percobaan}

Penelitian ini menggunakan Rancangan Acak Lengkap (RAL) faktorial, dengan dua faktor yaitu faktor pertama jenis jahe (gajah, emprit, dan merah) dan faktor kedua lama pengeringan (18, 20 dan 22 jam).

Perlakuan kedua faktor tersebut akan diperoleh kombinasi perlakuan dan masingmasing perlakuan diulang sebanyak tiga kali. Data yang diperoleh dianalisis dengan uji sidik ragam pada jenjang nyata 0,05 dan dilanjutkan dengan Duncan Multiple Range Test. 
TAHAPAN PENELITIAN

\section{Pembuatan Ekstrak Jahe}

Jahe dicuci menggunakan air mengalir, kemudian jahe dikupas, kemudian diparut dan disaring menggunakan kain saring. Proses terakhir adalah pengendapan ekstrak jahe selama 10 menit, sehingga didapat ekstrak jahe dan yang diambil adalah fitratnya.

\section{Pembuatan Manisan Tomat}

Buah tomat dicuci, kemudian ditusuktusuk menggunakan tusuk gigi, dan direndam kedalam kapur sirih selama 5 jam. Setelah direndam, buah tomat dicuci kembali kemudian di steam blanching selama 3 menit dengan suhu $90^{\circ} \mathrm{C}$. Setelah itu buah tomat dimasak dengan larutan gula sebesar 40\% hingga buah tomat mengecil. Tomat kemudian ditiriskan dan dikeringkan sesuai perlakuan $(18,20$, dan
22 jam).

\section{Cara Pengumpulan Data}

Analisisyang digunakan dalam penelitian ini yaitu analisis kimia, fisika dan uji organoleptik. Analisis kimia dan fisika terdiri dari aktivitas antioksidan (Yen dan Chen, 1995), analisis kadar air dengan destilasi Bidwen Sterling (AOAC, 1992), analisa kadar gula total dengan metode luff schroll (AOAC, 1970), Analisis kadar $\beta$ karoten dengan metode Carr Price (AOAC, 1992), analisis pH (AOAC, 2005). dan uji organoleptik dengan metode scoring test (Kartika et al., 1988) meliputi: warna, rasa tomat, flavor jahe, kealotan, aroma jahe dan kesukaan keseluruhan.

\section{HASIL DAN PEMBAHASAN}

\section{Analisis Kimia}

Tabel 1. Rangkuman Hasil Analisis Kimia dan Fisika Kurma Tomat

\begin{tabular}{|c|c|c|c|c|c|c|}
\hline \multirow[t]{2}{*}{ Jenis Jahe } & \multirow{2}{*}{$\begin{array}{c}\text { Lama } \\
\text { pengeringan }\end{array}$} & \multicolumn{5}{|c|}{ Analisis Kimiawi } \\
\hline & & $\begin{array}{c}\text { Kadar } \\
\text { Antioksidan }\end{array}$ & $\begin{array}{c}\text { Kadar } \\
\text { Air }\end{array}$ & $\begin{array}{c}\text { Kadar } \\
\text { Gula }\end{array}$ & $\mathrm{pH}$ & $\beta$ karoten \\
\hline Jahe Emprit & $\begin{array}{l}18 \text { jam } \\
20 \text { jam } \\
22 \text { jam }\end{array}$ & $\begin{array}{l}27,12^{\mathrm{g}} \\
26,00^{\mathrm{f}} \\
25,44^{\mathrm{e}}\end{array}$ & $\begin{array}{l}20,76^{d} \\
18,80^{c} \\
14,36 a^{b}\end{array}$ & $\begin{array}{l}39, \mathrm{O1}^{\mathrm{c}} \\
35,57^{\mathrm{b}} \\
33,42^{\mathrm{a}}\end{array}$ & $\begin{array}{l}5,7^{\mathrm{f}} \\
5,5^{\mathrm{cde}} \\
5,3^{\mathrm{abc}}\end{array}$ & $\begin{array}{l}11,5^{\mathrm{h}} \\
10,68^{\mathrm{g}} \\
9,60^{\mathrm{f}} \\
\end{array}$ \\
\hline Jahe Gajah & $\begin{array}{l}18 \text { jam } \\
20 \text { jam } \\
22 \text { jam }\end{array}$ & $\begin{array}{l}22,36^{\mathrm{ac}} \\
19,65^{\mathrm{b}} \\
17,13^{\mathrm{a}}\end{array}$ & $\begin{array}{l}20,10^{d} \\
18,20^{c} \\
15,10^{b} \\
\end{array}$ & $\begin{array}{l}39,23^{\mathrm{c}} \\
34,86^{\mathrm{b}} \\
33,35^{\mathrm{a}}\end{array}$ & $\begin{array}{l}5,6^{\mathrm{ef}} \\
5,5^{\mathrm{de}} \\
5,3^{\mathrm{abc}}\end{array}$ & $\begin{array}{l}6,33^{\mathrm{c}} \\
5,65^{\mathrm{b}} \\
4,38^{\mathrm{a}}\end{array}$ \\
\hline Jahe Merah & $\begin{array}{l}18 \text { jam } \\
20 \text { jam } \\
22 \text { jam }\end{array}$ & $\begin{array}{l}23,57^{d} \\
21,89^{c} \\
19,47^{b} \\
\end{array}$ & $\begin{array}{l}20,53^{\mathrm{d}} \\
18,43^{\mathrm{c}} \\
13,80^{\mathrm{a}} \\
\end{array}$ & $\begin{array}{l}39,15^{\mathrm{c}} \\
34,86^{\mathrm{b}} \\
32,92^{\mathrm{a}} \\
\end{array}$ & $\begin{array}{l}5,8^{\mathrm{f}} \\
5,3^{\mathrm{ab}} \\
5,2^{\mathrm{a}} \\
\end{array}$ & $\begin{array}{l}8,64^{\mathrm{e}} \\
7,65^{\mathrm{d}} \\
6,45^{\mathrm{c}} \\
\end{array}$ \\
\hline
\end{tabular}

\section{Aktivitas antioksidan}

Hasil analisa sidik ragam menunjukkan bahwa aktivitas antioksidan pada kurma tomat dengan perlakuan penambahan jenis jahe, lama pengeringan, dan kombinasi perlakuan keduanya berbeda nyata. Aktivitas antioksidan tertinggi pada kurma tomat sebesar $27,12 \%$, diperoleh melalui perlakuan penambahan jahe emprit dengan lama pengeringan 18 jam, sedangkan untuk aktivitas antioksidan terendah pada kurma tomat sebesar $17,11 \%$ diperoleh pada perlakuan penambahan jenis jahe gajah dan lama pengeringan $22 \mathrm{jam}$. Hal ini bisa terjadi karena dari ketiga jenis jahe tersebut kandungan gingerol paling tinggi terdapat pada jahe emprit, kemudiam jahe merah, dan yang paling rendah adalah jahe gajah (Shahidi dan Nackz, 1995).

Perlakuan lama pengeringan juga memiliki pengaruh yang nyata pada hasil aktivitas antioksidan kurma tomat. Semakin lama proses pengeringan yang dilakukan maka aktivitas antioksidan akan semakin menurun. Sesuai dengan pendapat (Suryaningrum dkk, 2006) bahwa antioksidan memiliki kelemahan yang sangat mudah rusak jika terkena oksigen, cahaya, suhu yang tinggi, dan proses pengeringan.

\section{Kadar Air}

Hasil analisis sidik ragam menunjukkan bahwa kadar air kurma tomat pada perlakuan lama pengeringan dan kombinasi perlakuan jenis jahe dan lama pengeringan berbeda nyata, sedangkan pada perlakuan jenis jahe berbeda tidak nyata. Kadar air kurma tomat tertinggi dihasilkan pada perlakuan penambahan jenis jahe emprit dengan lama pengeringan selama 18 jam yaitu sebesar 20,76\%. Hasil kadar air kurma 
tomat pengeringan yang terendah sebesar 13,80\% dihasilkan oleh kurma tomat dengan perlakuan penambahan jenis jahe gajah dan lama pengeringan selama 22 jam.

Pada perlakuan lama pengeringan kadar air semakin menurun seiring dengan semakin lama proses pengeringan kurma tomat. Hal ini selaras dengan pendapat Winarno (1982) bahwa semakin lama waktu yang digunakan dalam proses pengeringan semakin sedikit pula kadar air yang didapat dikarenakan semakin banyak air yang menguap.

\section{Kadar Gula}

Hasil analisis sidik ragam menunjukkan bahwa kandungan gula total pada penambahan jenis berbeda tidak nyata. Perlakuan lama pengeringan dan kombinasi perlakuan keduanya berbeda nyata. Kadar gula total kurma tomat tertinggi sebesar 39,235\% dengan perlakuan penambahan jahe gajah dan lama pengeringan selama 18 jam, sedangkan kadar gula total kurma tomat terendah sebesar 32,9281\% dengan perlakuan penambahan jahe merah dengan lama pengeringan selama 22 jam.

Kadar gula total pada perlakuan lama pengeringan memiliki hasil yang berbeda nyata dan semakin menurun seiring dengan semakin lama perlakuan pengeringan yang diberikan. Selaras dengan pendapat Kertenzs (1951) menyatakan bahwa semakin tinggi suhu maka ikatan hemiselulosa akan semakin banyak yang terputus sehingga kemurnian pektin akan meningkat dan mengakibatkan kadar gula total semakin menurun.

\section{pH}

Analisis sidik ragam menunjukkan bahwa nilai $\mathrm{pH}$ kurma tomat berbeda tidak nyata, sedangkan nilai $\mathrm{pH}$ kurma tomat dengan perlakuan lama pengeringan dan kombinasi perlakuan keduanya berbeda nyata. pH tertinggi sebesar 5,8 pada perlakuan penambahan jenis jahe merah dengan lama pengeringan selama 18 jam, sedangkan untuk $\mathrm{pH}$ terendah sebesar 5,2 dengan perlakuan penambahan jenis jahe merah dan lama pengeringan selama 22 jam.

Perlakuan lama pengeringan memiliki hasil yang berbeda nyata, yaitu semakin lama proses pengeringan yang diberikan maka semakin $\mathrm{pH}$ kurma tomat semakin menurun. Terjadinya perubahan $\mathrm{pH}$ semakin menurun pada kurma tomat seiring dengan semakin lama suhu pengeringan, dikarenakan suhu dan lama pengeringan berpengaruh pada penguapan air. Syarief dan Irawati (1988) berpendapat bahwa Semakin berkurangnya kandungan air pada suatu bahan maka konsentrasi ion $\mathrm{H}^{+}$ pada bahan pangan semakin bertambah dan konsentrasi asam semakin tinggi.

\section{$\beta$ Karoten}

Hasil analisis sidik ragam menunjukan bahwa kandungan $\beta$ karoten pada kurma tomat dengan penambahan jenis jahe, perlakuan lama pengeringan dan kombinasi perlakuan keduanya berbeda nyata. Kadar $\beta$ karoten kurma tomat yang tertinggi sebesar $11,51 \%$ dengan perlakuan penambahan jenis jahe emprit dan lama pengeringan selama 18 jam, sedangkan untuk kadar $\beta$ karoten yang paling rendah sebesar $4,3823 \%$ dengan perlakuan penambahan jenis jahe gajah dengan lama pengeringan selama 22 jam.

Perlakuan lama pengeringan kadar $\beta$ karoten juga memiliki hasil yang semakin menurun seiring dengan semakin lama proses pengeringan. Hal ini selaras dengan pendapat Walford (1980) yang menyatakan bahwa karoten akan mudah teroksidasi ketika terkena udara atau sinar. 


\section{Uji Organoleptik}

\begin{tabular}{|c|c|c|c|c|c|c|}
\hline \multirow[t]{2}{*}{ Jenis Jahe } & \multirow{2}{*}{$\begin{array}{c}\text { Lama } \\
\text { Pengeringan }\end{array}$} & \multicolumn{5}{|c|}{ Uji Organoleptik } \\
\hline & & Rasa & Warna & kealotan & $\begin{array}{l}\text { Aroma } \\
\text { Jahe }\end{array}$ & $\begin{array}{c}\text { Kesukaan } \\
\text { Keseluruhan }\end{array}$ \\
\hline \multirow[t]{3}{*}{ Jahe Emprit } & 18 jam & $2,1^{\mathrm{a}}$ & $1,8^{\mathrm{a}}$ & $1,7^{\mathrm{ab}}$ & $2,3^{\mathrm{ab}}$ & $2,4^{a}$ \\
\hline & 20 jam & $2, \mathrm{O}^{\mathrm{a}}$ & $1,8^{\mathrm{a}}$ & $2,1^{\mathrm{ab}}$ & $2,5^{\mathrm{ab}}$ & $2,2^{\mathrm{a}}$ \\
\hline & 22 jam & $1,7^{\mathrm{a}}$ & $2,1^{\mathrm{ab}}$ & $2,6^{\mathrm{b}}$ & $3,1^{b}$ & $2,2^{\mathrm{a}}$ \\
\hline \multirow[t]{3}{*}{ Jahe Gajah } & 18 jam & $1,6^{a}$ & $2,7^{\mathrm{ab}}$ & $2,8^{b}$ & $2,2^{\mathrm{ab}}$ & $2,8^{a}$ \\
\hline & 20 jam & $1,5^{\mathrm{a}}$ & $2,2^{\mathrm{ab}}$ & $2,0^{a b}$ & $2, \mathrm{O}^{\mathrm{a}}$ & $2,5^{\mathrm{a}}$ \\
\hline & 22 jam & $1,7^{\mathrm{a}}$ & $2,4^{\mathrm{ab}}$ & $2,6^{\mathrm{ab}}$ & $2,7^{\mathrm{ab}}$ & $1,9^{\mathrm{a}}$ \\
\hline \multirow[t]{3}{*}{ Jahe Merah } & 18 jam & $1,7^{\mathrm{a}}$ & $2,2^{\mathrm{ab}}$ & $2,3^{\mathrm{ab}}$ & $3,2^{b}$ & $2,3^{a}$ \\
\hline & 20 jam & $1,7^{\mathrm{a}}$ & $2,6^{\mathrm{ab}}$ & $2,6^{\mathrm{b}}$ & $3,0^{a b}$ & $2,3^{\mathrm{a}}$ \\
\hline & 22 jam & $2, \mathrm{O}^{\mathrm{a}}$ & $2,8^{b}$ & $2,6^{\mathrm{b}}$ & $2,6^{\mathrm{ab}}$ & $2,1^{\mathrm{a}}$ \\
\hline
\end{tabular}

Keterangan :

Rasa Tomat $\quad$ : Angka tertinggi menunjukkan rasa tomat semakin terasa

Warna : Angka tertinggi menunjukkan warna tomat semakin nyata

Kealotan : : Angka tertinggi menunjukkan kealotan kurma tomat semakin alot

Aroma Jahe : : Angka tertinggi menunjukkan aroma jahe semakin terasa

Kesukaan keseluruhan : Angka tertinggi menunjukkan kurma tomat semakin disukai

\section{Rasa Tomat}

Hasil analisis statistik menunjukan bahwa perlakuan penambahan jenis jahe lama pengeringan, dan kombinasi keduanya berbeda tidak nyata terhadap rasa tomat pada kurma tomat. Panelis memberi nilai paling terasa tomat sebesar 2,o pada perlakuan penambahan jahe emprit dan lama pengeringan selama 20 jam, sedangkan untuk penilaian panelis yang memilki rasa tomat paling rendah yaitu 1,5 dengan perlakuan penambahan jenis jahe gajah dan lama pengeringan selama 20 jam.

Dapat diketahui bahwa penambahan jenis jahe dan lama pengeringan tidak berpengaruh nyata terhadap rasa tomat pada kurma tomat. Sebagian besar panelis menilai bahwa tidak ada rasa tomat pada kurma tomat. Hal ini dapat terjadi karena proses pengeringan yang lama sehingga rasa tomat menjadi hilang, selain itu perlakuan penambahan jenis jahe juga dapat mempengaruhi rasa yang dihasilkan, jahe memiliki senyawa oleoresin dan memiliki rasa serta flavor yang sangat kuat (Paimin dan Murhananto, 200o).

\section{Warna}

Analisis sidik ragam dapat dilihat bahwa penambahan jenis jahe berbeda nyata terhadap warna kurma tomat, sedangkan pada perlakuan lama pengeringan dan kombinasi keduanya berbeda nyata pada warna kurma tomat dengan penambahan jenis jahe dan lama pengeringan.
Penilaian panelis mengenai warna pada kurma tomat dengan penambahan jenis jahe dan lama pengeringan yang tertinggi adalah 2,8 dengan perlakuan penambahan jenis jahe merah dan lama pengeringan selama 22 jam, sedangkan penilaian panelis yang terendah adalah 1,8 dengan perlakuan penambahan jahe emprit dengan lama pengeringan selama 18 dan 20 jam.

Penambahan jenis jahe, terutama jenis jahe merah dapat mempengaruhi warna kurma tomat dikarenakan jahe merah ini memiliki warna yang khas dibanding jenis jahe yang lain yaitu memiliki warna yang kemerah-merahan hingga jingga (Suprapti, 2003).

\section{Kealotan}

Hasil analisa sidik ragam dapat dilihat bahwa perlakuan penambahan jenis jahe, perlakuan lama pengeringan, dan kombinasi perlakuan keduanya berbeda nyata terhadap kealotan kurma tomat. Penilaian panelis mengenai kealotan kurma tomat dengan penambahan jenis jahe dan lama pengeringan tertinggi adalah 2,6 pada perlakuan semua jenis jahe dengan lama pengeringan selama 22 jam, sedangkan untuk penilaian panelis terendah terdapat pada perlakuan penambahan jenis jahe gajah dengan lama pengeringan selama 18 jam.

\section{Aroma Jahe}

Hasil analisa sidik ragam dapat diketahui bahwa penambahan jenis jahe berbeda nyata 
terhadap aroma jahe kurma tomat, sedangkan untuk perlakuan lama pengeringan dan kombinasi pelakuan keduanya berbeda nyata terhadap aroma kurma tomat. Penilaian panelis mengenai aroma jahe pada kurma tomat paling tinggi pada perlakuan penambahan jenis jahe merah dengan lama pengeringan selama 18 jam yaitu memiliki nilai 3,2 sedangkan untuk penilaian panelis yang paling rendah sebesar 2,o pada perlakuan penambahan jenis jahe gajah dengan lama pengeringan selama 20 jam.

Jenis jahe memiliki pengaruh nyata terhadap aroma jahe pada kurma tomat, terutama pada penambahan jenis jahe merah. Hal ini dapat terjadi karena jahe merah memiliki rasa yang paling pedas dibanding dengan dua jenis jahe yang lainnya (Suprapti, 2003).

\section{Kesukaan Keseluruhan}

Hasil analisis sidik ragam dapat diketahui bahwa penambahan jenis jahe, lama pengeringan, dan kombinasi perlakuan keduanya berbeda tidak nyata pada kesukaan keseluruhan panelis pada kurma tomat dengan penambahan jenis jahe dan lama pengeringan. Penilaian panelis rata-rata memiliki kesukaan kurma tomat dengan perlakuan penambahan jenis jahe gajah dengan pengeringan selama 18 jam. Pengeringan 22 jam kurang disukai karena tekstur kurma tomat yang agak alot dibanding dengan proses pengeringan 18 dan 20 jam.

\section{KESIMPULAN}

Karakteristik kimia dan organoleptik kurma tomat dengan penambahan jenis jahe (gajah, emprit, merah) dan lama pengeringan $(18,20$, 22 jam) menunjukkan bahwa antioksidan, $\beta$ karoten, kadar air, kadar abu, semakin menurun, sedangkan untuk $\mathrm{pH}$ dan kadar abu semakin meningkat. Jenis jahe dan lama pengeringan yang menghasilkan kurma tomat yang paling disukai konsumen adalah perlakuan penambahan jenis jahe gajah dengan lama pengeringan selama 18 jam. Perlakuan penambahan jahe yang disukai panelis adalah dengan penambahan jenis jahe gajah, karena memiliki rasa yang tidak terlalu pedas dibanding dengan jenis jahe merah dan jahe emprit.

\section{DAFTAR PUSTAKA}

Alda, L. M., Gogoasa, I., Bordean, D.M., Gergen, I., Alda., Moldoven, C., dan
Nita, L., 2009. Lycopane Content of Tomatoes and Tomato Products. Journal of Agroalimentary Processes and Tegnologies, 15(4):540-542.

Association of Official Analytical Chemist.1970. Official Methods of Analysis of The Association of Ofificia Analitycal Chemist. Washington. DC: AOAC

Astuti, J.T., 1979. Pengaruh Penambahan $\mathrm{NaHSO}_{3}$ Blanching dan Suhu Pengeringan terhadap Mutu Kelapa Parut Kering selama Penyimpanan. Bogor: Fatemeta Institut Pertanian Bogor.

Budiman, M.H., 2008. Uji Stabilitas Fisik dan Aktivitas Antioksidan Sediaan Krim yang Mengandung Ekstrak Kering Tomat (Solanum lycopercicum L,). Skripsi. Jakarta: Departemen Farmasi. Fakultas Matematika dan Ilmu Pengetahuan Alam, Universitas Indonesia.

Darwis, S.N., Indo, M., dan Hasiyah, S, 1991. Tumbuhan Obat Family Zingiberaceae. Bogor: Pusat Penelitian dan Pengembangan Industri.

Guenther, E., 1952. The Essential Oil. New York: D. Von Nostard Co. Inc . P: 72

Kartika B., P. Hastuti dan W. Supartomo. 1998. Pedoman Uji Inderawi Bahan Pangan. Yogyakarta: Pusat Antar Universitas Pangan dan Gizi Universitas Gadjah Mada.

Kertesz, Z, I. 1951. The Pectic Substances. New York: Interscience Pub. Inc.

Shahidi, F., dan Naczk, M.,1995. Food Phenolics. Lancester-Basel: Techomic Pub.Co.Inc.

Suprapti, M. L., 2003. Aneka Awetan Jahe. Yogyakarta: Kanisius.

Suryaningrum, T.D., Wikanda, T., dan Kristiana, H., 20o6. Uji Aktivitas Senyawa Antioksidan dari Rumput Laut Coklat (Sargasum crassifolium) sebagai Antikosgulan, Jurnal Pascapanen dan Bioteknologi Kelautan dan Perikanan (1) : 51-63.

Syarief, R. dan Irawati, A., 1988. Pengetahuan Bahan untuk Industri Pangan. Jakarta: Medyatama Sarana Perkasa.

Paimin, F. B., dan Muhananto, 200o. Budidaya, Pengolahan, Perdagangan Jahe. Jakarta: Penebar Swadaya.

Walford, J. 1980. Development in Food Colours-1 Applied Science. London: Publisher Ltd.

Winarno, F.G. 1982. Kimia Pangan dan Gizi. Jakarta: Gramedia Pustaka Utama. 